\title{
Supporting Success: Aboriginal Students in Higher Education
}

\author{
Cynthia J. Gallop
}

Mount Royal University

Nicole Bastien

\begin{abstract}
For most Aboriginal students in Canada, the term "success" in postsecondary education is more complicated than the mainstream notions of higher socioeconomic status and career advancement. Historically, "success" for Aboriginal peoples in postsecondary education was linked to issues of assimilation, since to be successful meant Aboriginal students had to completely adapt to the mainstream values and behaviours of the postsecondary institutions. Today, higher education is recognized as an important tool for capacity building and assisting Aboriginal communities to achieve their goals of self-determination and self-government. This paper presents some of the findings of a qualitative study conducted in a midsized Canadian postsecondary institution. Findings from the study suggest that if Canadian postsecondary institutions are committed to retaining Aboriginal students, these institutions need to better understand how to create positive and supportive relationships between Aboriginal students and their peers and instructors. The development of these positive relationships then needs to be formalized and incorporated into both institutional planning and faculty instructional support.
\end{abstract}

\section{Résumé}

Pour la plupart des étudiants autochtones du Canada, la notion de " réussite » dans un contexte d'éducation postsecondaire est plus complexe que les notions communément admises par rapport à l'avancement professionnel et à l'amélioration du statut socioéconomique. D'un point de vue historique, la " réussite » des peuples autochtones en termes d'éducation postsecondaire est liée aux questions d'assimilation. En effet, réussir signifiait de s'adapter 
totalement aux habitudes et aux valeurs des établissements postsecondaires de l'époque. De nos jours, on reconnait le rôle important que joue l'éducation postsecondaire dans le renforcement des capacités des communautés autochtones afin qu'elles atteignent leurs objectifs d'autodétermination et d'autonomie gouvernementale. Cet article présente les résultats d'une étude qualitative menée dans un établissement postsecondaire canadien de taille moyenne. Les résultats suggèrent que les établissements désireux d'encourager les étudiants autochtones à poursuivre leurs études postsecondaires se doivent de mieux comprendre comment forger des rapports positifs entre étudiants, Autochtones et professeurs afin de fournir un meilleur accompagnement aux étudiants autochtones. Ces relations positives devront ensuite être officialisées et intégrées dans le cadre d'une planification institutionnelle et d'un soutien pédagogique aux professeurs.

\section{Introduction}

For most Aboriginal students in Canada, achieving "success" in postsecondary education involves more than achieving the mainstream ideals of higher socioeconomic status and career advancement (Pidgeon, 2008b). Currently, most mainstream institutions in Canada define academic success as

external measures and performance outcomes related to intellectual achievement. For example, GPA, courses completed, and graduation are measures used by universities to identify successful students. By mainstream standards, a successful Aboriginal student would be like any other student, by completing his or her course work with a high GPA and graduating from his or her program in a timely manner. (Pidgeon, 2008a, p. 144)

However, according to Pidgeon's (2008a) research findings, success for Aboriginal peoples in postsecondary education also includes the "ability to maintain cultural integrity," "finding their gifts," and "responsibility of reciprocity." Specifically, "maintaining cultural integrity," involves "having a sense of oneself and keeping hold of one's Indigenous understandings" (Pidgeon, 2008a, p. 143). An Aboriginal student's ability to "find their gifts" was defined as the capacity to do whatever a person envisions for himself or herself (Pidgeon, 2008a). The "responsibility of reciprocity" is the ability to give back to larger Indigenous communities (Pidgeon, 2008a). As such, for many Aboriginal students higher education is recognized as an important tool for capacity building and assisting Aboriginal communities to achieve their goals of self-determination and self-government (Battiste, Bell, \& Findlay, 2002; Danziger, 1996; Pidgeon, 2008a; Stonechild, 2006; Wildcat, 2001). Unfortunately, given that many Aboriginal students experience far more marginalization than their non-Aboriginal peers, they are more likely to face challenges navigating university and college systems, becoming fully engaged in their academic pursuits (Manifold \& Rambur, 2001; Pidgeon, 2008a, 2008b; Pijl-Zieber \& Hagen, 2011), and ultimately achieving success on their terms, and as they define it.

Informal conversations between Aboriginal students and the teaching faculty members of this study inspired this research project. It was during these conversations that students raised some of their experiences, both positive and negative, within this mid- 
sized, Western Canadian undergraduate institution. The instructors decided to further explore this topic by putting together an interdisciplinary team of researchers from the fields of social work, nursing, physical education, and justice studies. Three researchers were employed as teaching faculty, and one as an administrator at the university. Over the course of several weeks in the spring of 2011, the four full-time researchers; an Aboriginal alumna employed as the part-time research coordinator; and three senior Aboriginal students, employed as part-time research assistants, developed a qualitative research project. The study involved recruiting Aboriginal student participants attending the university and attempted to better understand their academic experiences through a combination of interviews and a focus group discussion. This paper presents some of the experiences of these students, and what supported and challenged their feelings of success in this institution.

\section{Literature Review}

\section{Overview of Aboriginal People in Canada}

It is important to note that Aboriginal students are not a homogeneous group in Canada. Although the Canadian government has grouped the First Nations, Inuit, and Métis people together and identified them as "Aboriginal," there are significant differences between First Nations peoples (with or without status), Métis, and Inuit. For example, the term "First Nations" began to acquire meaning around 1979, when the National Indian Brotherhood renamed their organization the Assembly of First Nations. This name change was meant to symbolize the growing politicization of these groups (Stonechild, 2006). Having said this, "the term 'Aboriginal' is frequently employed to impart the message that government policy in this area needs to be construed in a much broader sense" (Stonechild, 2006, p. 6). All of the participants of this study identified themselves as Aboriginal. So, for the purposes of this article, the term "Aboriginal" will be used throughout. This particular word usage is not meant to minimize or privilege the unique histories, experiences, beliefs, languages, and cultural practices of individual persons or communities, but instead to represent Indigenous Canadian-born identity and experiences, regardless of formal legal status or community.

In Canada, Aboriginal people make up $4.3 \%$ of the overall population, and $6.2 \%$ of the population in Alberta (Statistics Canada, 2013). The overall percentage varies from province to province and can be as low as 1.6\% (Prince Edward Island) or as high as 16.7\% (Manitoba; Statistics Canada, 2013). Education has become a central issue in Canada, as its Aboriginal population is considerably underrepresented on college and university campuses (Tomaszewski, Powell, Gallop, London, \& Gyles, 2011). A report released by Statistics Canada (2008) found that while $51 \%$ of the non-Aboriginal population aged 25 to 64 had completed a college certificate, diploma, or university degree, only $35 \%$ of the Aboriginal population in the same age group had done so. Furthermore, while 23\% of Canada's non-Aboriginal population had a university degree in 2006, only $8 \%$ of Aboriginal people had successfully completed a degree (Statistics Canada, 2008).

Historically, Aboriginal peoples of Canada have experienced oppression due to the previous educational systems set in place specifically for this population. The most prominent form of past institutional injustice was experienced via residential schools, with the last 
one closing its door in 1996 (Health Canada, 2013). The inspiration and motivation behind the development of the residential school system are captured in a quote from John A. Macdonald during his May 9, 1883, address to the Canadian Members of Parliament:

When the school is on the reserve, the child lives with his parents who are savages; he is surrounded by savages, and though he may learn to read and write, his habits and training and mode of thought are Indian. He is simply a savage who can read and write. It has been strongly pressed upon myself, as head of the Department [of Indian Affairs], that Indian children should be withdrawn as much as possible from the parental influence ... where they will acquire the habits and modes of thought of white men. (as cited in Stonechild, 2006, p. 9)

In its blatant attempt to assimilate Aboriginal children into mainstream culture, the government of Canada partnered with churches, creating laws that segregated Aboriginal children from their families and culture. It was also noted in a survey conducted in 1948 that $40 \%$ of residential school teachers had no professional educational training. Instead, "many had simply been hired on the basis of 'missionary zeal"' (Stonechild, 2006, p. 20). The lessons were often repetitive and boring, which led to low academic engagement and achievement (Stonechild, 2006).

The 1996 report generated by the Royal Commission on Aboriginal Peoples (RCAP) also explored the impact of Canada's education system on its First Nations people. The report concluded that in addition to significant challenges within the $\mathrm{K}-12$ education system, many colleges and universities also tended to be assimilative and that "everyone is expected to fit in" (RCAP, 1996, p. 476). Today, research still indicates a strong correlation between the specific educational systems set out for Aboriginal people of the past, and the current experiences they have in the prominent Eurocentric educational institutions (Bastien, 2004; Harrington \& Pavel, 2013; Ireland, 2009; Pidgeon, Archibald, \& Hawkey, 2014; Waller et al., 2002). Kirkness and Barnhardt (2001) note that postsecondary schools have increased the pressure on Aboriginal students to adjust and shift to the culture of the institutions, which is similar to the historic Aboriginal colonial experiences in Canada. In addition, Aboriginal students are still confronted with marginalization on a day-to-day basis. For instance, Aboriginal students who experience negative stereotypes and prejudices from other students or faculty are further disadvantaged by inaccurate portrayals of Aboriginal peoples in the curriculum (Harrington \& Pavel, 2013; Ireland, 2009; Kirkness \& Barnhardt, 2001; Timmons, 2009). As such, the colonial legacy of Canada's educational system cannot be ignored within higher education, primarily because this system has been, and continues to be, both a hidden and overt model of colonization (Antone, 2000; Barnhardt, 1992, 2002; Battiste, 2000, Battiste \& Barman, 1995; Battiste \& Henderson, 2000; Deloria, 2001; Pidgeon, 2008b; Urion, 1999).

\section{Factors Leading to Aboriginal Student Success}

Social engagement and formal community-building efforts. Although often regarded as a personal experience from a Western perspective, learning is very much a social activity (Marshall, 1992; McCaslin \& Good, 1996; Shuell, 1996; Vygotsky, 1978; Wigfield , Eccles, \& Rodriguez, 1996), which includes the learner and his or her teach- 
ers, mentors, peers, and community (Webb \& Palincsar, 1996; Wigfield et al., 1996). Research indicates that when Aboriginal students are afforded the opportunity to engage in culture-specific activities, they experience a sense of balance, a common Aboriginal value where the mental, emotional, physical, and spiritual domains are equally acknowledged and incorporated (Bastien, 2004; Harrington \& Pavel, 2013; Ireland, 2009; Kirkness \& Barnhardt, 2001; Kuokkanen, 2007; Timmons, 2009; Waller et al., 2002). This has a ripple effect for many learners, whereby there is an increase in self-esteem, confidence, and capacity, and subsequently, Aboriginal students are more equipped to face challenges within the educational milieu (Martin \& Kipling, 2006). Pidgeon (2008b) has also suggested that having educational programs that support strong cultural identity can lead to "cultural integrity":

Cultural integrity is linked to the formation of cultural capital. For example, the college preparation program described in Tierney and Jun's (2001) study connected students to social networks (i.e., peer groups, Aboriginal staff, and faculty) and developed students' cultural capital (i.e., useable resources and skills) required to survive college. Although mainstream institutions have been criticized for lack of emotional and psychological supports (Wildcat, 2001d), this particular program is an example of how to meet the needs of Aboriginal students. (p. 351)

Institutions that possess an Aboriginal student centre, focused on promoting culture-specific activities and resources, often produce outcomes that can lead to higher levels of Aboriginal student academic and social engagement. Subsequently, these centres contribute to retaining this group within the postsecondary education system (Guillory \& Wolverton, 2008; Martin \& Kipling, 2006). For example, providing an environment where Aboriginal students are able to participate in social and cultural activities such as powwows, potlucks, and outings, while building a network of Aboriginal peers, has been found to create a positive impact of belonging, acceptance, and validation of lived experiences (Martin \& Kipling, 2006).

In addition to opportunities to connect with other Aboriginal students, support from faculty and non-Aboriginal peers is also significant. Building relationships outside of the classroom fosters an atmosphere in which Aboriginal learners can adjust psychologically and grow academically (Alcorn \& Levin, 2000; Guillory \& Wolverton, 2008; Martin \& Kipling, 2006). Relationship-building activities engage Aboriginal students and build upon their sense of worthiness and "fitting in." In addition, supports from faculty and non-Aboriginal peers promote validation and acceptance, in turn fostering a support and ally network (Kirkness \& Barnhardt, 2001).

Role models and mentors have also been acknowledged as important inspiration for individuals. Research suggests that faculty and staff who act as role models and mentors can cultivate a supportive and empowering environment for arriving and existing Aboriginal students (Archibald, Pidgeon, \& Hawkey, 2010; Guillory \& Wolverton, 2008; JacksonBarrett, 2011; Timmons, 2009). Specifically, teaching faculty can aid in developing these roles by actively engaging with Aboriginal students and building authentic relationships that foster motivation in pursuing and completing postsecondary education. In addition, representation of Aboriginal academics can further reflect and instill determination in the postsecondary experience for these learners (Guillory \& Wolverton, 2008). 
Formal Aboriginal mentorship programs have produced results that are specialized to the students' specific needs and foster family engagement and involvement, with many of these programs creating improvement in self-esteem, self-efficacy, and graduation rates (Beaudin, Gunn, Heffernan, \& Tailfeathers, 2006; Pidgeon et al., 2014). This positive relational experience demonstrates that connection is vital to overall Aboriginal student success. Additionally, research indicates that many Aboriginal students aspire to become role models themselves and to inspire others, often in their own communities (Alcorn \& Levin, 2000; Guillory \& Wolverton, 2008; Huffman, 2001; Kirkness \& Barnhardt, 2001; Pidgeon et al., 2014). This desire to provide a future for self is extended once again to the community and is a form of giving back. Mentorship interactions have significant effects on the students' confidence, resilience, and self-esteem, contributing to an encouraging and effective postsecondary experience (Pidgeon et al, 2014).

Cultural identity. Strong cultural identity has been found to act as a protective factor for many Aboriginal students when entering, continuing, and completing postsecondary education. Strong cultural identity acts as a way for students to persist in an educational system that is not necessarily constructed with the Aboriginal student in mind (Huffman, 2001; Ireland, 2009; Kirkness \& Barnhardt, 2001; White Shield, 2003). As such, Aboriginal students who possess strong cultural identity are more likely to have the confidence to engage in a new culture with less fear of assimilation, or loss of culture (Kirkness \& Barnhardt, 2001).

Self-efficacy. Self-efficacy has become an important concept for better understanding both student learning and engagement (Linnenbrink \& Pintrich, 2003). Although a number of researchers have studied and defined self-efficacy (Bandura, 1986; Linnenbrink \& Pintrich, 2003; Pajares, 1996), Linnenbrink \& Pintrich (2003) summarize the concept nicely by stating self-efficacy answers the question "Can I do this task in this situation?" Self-efficacy is different from self-esteem in that "self-efficacy concerns students' beliefs that they can do something" (Linnenbrink \& Pintrich, 2003, p. 121), whereas self-esteem involves the individual's emotional reactions to her or his actual accomplishments (Linnenbrink \& Pintrich, 2003). Research indicates that individual factors such as commitment, visualizing future and destiny, reflection, valuing education, self-esteem, and educational self-efficacy are crucial in each student's commitment to postsecondary education (Linnenbrink \& Pintrich, 2003). Kurpius, Payakkakom, Rayle, Chee, and Arredondo (2008) also found these factors to be important for Native American students.

Not surprisingly, the relationship between self-efficacy and learning engagement has also been found to be circular, in that the more the student is engaged and the more they learn, the more self-efficacy they will have. Individuals who have little or low self-efficacy tend to be plagued with self-doubt and often give up on tasks much more easily than individuals who have strong efficacy beliefs (Linnenbrink \& Pintrich, 2003). Low outcome beliefs, or learned helplessness, have also been linked to low efficacy and a long personal history of failure, which these individuals believe is uncontrollable and involves only them. Researchers have also found that individuals who have low self-efficacy are less likely to seek help or support when they run into difficulty (Karabenick \& Knapp, 1991; Linnenbrink \& Pintrich, 2003; Newman, 1990; Ryan \& Pintrich, 1997). 


\section{Method}

This study used a qualitative method with elements of the participatory action research (PAR) approach to inquiry (Pidgeon \& Hardy Cox, 2002) to better understand the experiences of Aboriginal students. Qualitative research methods are typically used when researchers wish to explore life experiences, different perspectives, and behaviours through a holistic framework (Holloway \& Wheeler, 2002; Khan, 2014). PAR, which is often described more as a general process than a specific method, is well suited to qualitative approaches because the critical and practical knowledge developed in PAR projects begins from an understanding of meaning (Kidd \& Kral, 2005; Smith, 1997). More specifically, PAR has been described as a "process in which people (researchers and participants) develop goals and methods, participate in the gathering and analysis of data, and implement the results in a way that will raise critical consciousness and promote change in the lives of those involved" (Kidd \& Kral, 2005, p. 187).

Social psychologist Kurt Lewin $(1946,1952)$, the leading pioneer of action research, described this approach to inquiry as spiral steps, "each of which is composed of planning, acting, observing, and evaluating the result of the action" (McTaggart, 1991, p. 170). In PAR, the spiral steps identified by Lewin are constantly evaluated and negotiated through "authentic participation" amongst all identified stakeholders in the project. $\mathrm{Au}-$ thentic participation involves all stakeholders setting the inquiry agenda, participating in data collection and analysis, and controlling the use of the outcomes and overall inquiry process (Tandon, 1988).

The faculty researchers had each become aware that a disproportionate number of students who identified as Aboriginal were struggling in some of the institution's programs. The faculty members wanted to better understand how teaching faculty were contributing to this problem, and more importantly, how they could begin to remedy it. However, given that the faculty researchers were all non-Aboriginal, each faculty member had to constantly ask himself or herself, and each other, how to conduct this inquiry without being oppressive, disrespectful, or too intrusive to the larger community of Aboriginal people represented in the study (Pidgeon \& Hardy Cox, 2002). To this end, former students were sought out and informally asked about their academic experiences in the institution and for advice on how to formally engage current students. In addition, the full-time faculty researchers also actively involved various Aboriginal stakeholders on campus, including the student's union-based Native student centre and the university-based Aboriginal support centre, as well as a local elder. Thus, members of the local Aboriginal community were aware of the project and approved it, ensuring the cultural sensitivity of the study and appropriateness of questions included in the interview tool.

This study asked the following questions: How do Aboriginal students enrolled in a mainstream postsecondary undergraduate institution understand and negotiate their academic experiences? What motivates them to attend a postsecondary institution, and what helps them remain there until they graduate?

\section{Participants and Recruitment}

Ideally, to be a full PAR project this inquiry would have involved all of the students as co-researchers. However, given that the Aboriginal student community is fairly small in 
this institution, it was likely that some of the student participants would be former, current, or future students of one of the full-time faculty researchers. It was deemed very important that students feel as comfortable as possible discussing their experiences without fear of consequences, or coercion. As such, to ensure the student participants, and their data, remained anonymous to the faculty researchers, the research coordinator conducted all participant recruitment for this study, with support from the research assistants.

The participants for this study were chosen exclusively from a midsized Western Canadian postsecondary institution, where approximately $3.25 \%$ of the total student body identify as Aboriginal. The criteria included full-time or part-time students who were enrolled at the institution, who self-identified as Aboriginal, First Nations, Métis, or Inuit, and who were at least 18 years of age or older. By means of both convenience and snowball sampling procedures, the participants of this study were recruited through the contact persons at the Native student centre and the Aboriginal support centre. In addition, a number of recruitment posters were placed around the institution.

In total, this study involved 14 Aboriginal student participants. Coincidentally, half of the respondents were female and half were male. The majority of respondents were between 18 and 24 years of age (almost 80\%; $n=11$ ), one was between 25 and 34, and two were between 35 and 44 years. Women and men were equally distributed in the different age groups. When asked about their family situation, none of the respondents indicated that they were married; almost $86 \%(n=12)$ were living without another adult; and the remainder were cohabiting. Three of the women and two of the men had children, and all five noted that they were the primary caregivers. Of these, two of the participants, both women, were living with a partner, whereas the other three were living alone with their children.

Half of the participants indicated they belonged to an Aboriginal community in Calgary, or in proximity to Calgary, which meant they could commute easily to the university. The remaining participants were from remote areas in the province $(n=3)$. Three were from neighbouring provinces, and one from a Northern territory. These participants had moved to Calgary and resided there while they attended the postsecondary institution. Two female and two male respondents indicated they spoke an Aboriginal language at home (in addition to English), and one person noted that the first language they learned was an Aboriginal language.

\section{Data Collection}

The research data were collected using in-depth, semistructured interview and focus group discussion formats. Originally, the faculty and student researchers felt a focus group data collection format would be more in line with the principles of PAR. In particular, we saw it as an opportunity to create community and collaborative sharing opportunities for the participants and student researchers. However, as Lewin $(1946,1952)$ suggested, action research often involves a reflective decision-making process that requires a fair amount of flexibility and focus on process. So, after encountering significant difficulty recruiting students to participate in group conversations, the research assistants and research coordinator began informally asking potential participants why they were hesitant to participate. Through these informal conversations, it was discovered that many participants did not feel comfortable discussing their personal experiences with other students 
present. Also, it was acknowledged by some students that there were two significant Aboriginal cultural groups on campus (Cree and Blackfoot), and many students did not feel comfortable mixing the groups. Therefore, the research assistants and coordinator suggested offering individual interviews as another option for participation for students who did not want to be in a focus group. The result was individual interviews conducted with seven participants, by either the research coordinator or one of the research assistants, and a single focus group, which included seven participants, facilitated by the coordinator and one of the assistants. Both the focus group and the individual interviews were conducted at the end of the 2011 winter semester. Each participant in this study took part in a 1- to 2-hour audiotaped focus group or personal interview.

\section{Data Analysis}

The constant comparison method was used to analyze the data for this project. All four faculty researchers, the research coordinator, and student research assistants individually read through the data, which consisted of transcriptions of one focus group discussion and seven interviews, as they were generated. Data were then grouped by each researcher into themes or "codes" and compared to new data as they came in. After individual analysis was complete, the researchers came together and compared individual findings or themes. If someone was not able to make the meetings, the researcher was asked to share his or her analysis with the primary investigator of the project. Most qualitative research recommends using an interrater reliability method for data analysis in order to strengthen the trustworthiness of the study (Leech \& Onwuegbuzie, 2007), and given that four of the researchers were in authority positions and non-Aboriginal, this last step was seen as crucial to maintaining the integrity of both the findings and the principles of the PAR approach.

\section{Study Limitations}

As this research involved using a nonprobability sample, the effects of this study will not be generalizable beyond this particular group or school. As such, this preliminary study is one step in attempting to better understand the academic experiences of $\mathrm{Ab}$ original students. In addition, a social desirability bias was also something considered when conducting this research. Given the nature of the questions about their perceived success or challenges with their academic programs, participants could have altered their responses in an attempt to avoid feeling shamed, exposed, or inadequate (Bernard, 2012). The researchers hoped to mitigate most of this bias by using peers as interviewers and focus group facilitators. However, power differentials could still exist. Therefore, interviewers were continually reminded to remain mindful of the power differentials and the impact they may have on the interview process, and to create an environment that provided sufficient conversational space for participants to feel shame and embarrassment without perceived repercussions (Bernard, 2012).

Although reliability and validity are not measured in the same way for qualitative research as they are for quantitative, confidence that the data collection and analysis are trustworthy and credible are very important in qualitative research. Recognizing that qualitative research is an iterative rather than linear process, steps were taken along the 
way between design and implementation to ensure congruence between the question formulation, literature review, participant recruitment, data collection strategies, and analysis (Morse, Barrett, Mayan, Olson, \& Spiers, 2002). One of the greatest benefits to being part of a PAR study with an interdisciplinary team is the number of built-in verification strategies from the beginning through to the end.

\section{Results}

The themes that emerged in this research fell into one of two categories: institutionbased services (health and wellness, academic advising, accessibility services, and specialized student services such as the Aboriginal support centre), and classroom- and teaching-based support.

\section{Supportive Institutional Space}

Aboriginal-centred education programs. A number of participants discussed seeking out this postsecondary institution because of the Aboriginal Education Program (AEP) offered at the university. This program is part of the academic support centre for Aboriginal students attending this institution. The services offered within this centre include cultural and spiritual advising, academic advising, counselling, tutoring, and a computer resource lab (Iniskim Centre, n.d.). The AEP is a university preparation program (UCEP) for students of Aboriginal ancestry. It is designed to meet the unique needs of Aboriginal students, who also may require advanced upgrading, particularly in math and English (Aboriginal Education Program, n.d.). As this participant stated, the AEP and services offered by the institution-based Aboriginal support centre created a postsecondary program that seemed safe and inviting:

Some of the main reasons why I chose [the school] was class size. I knew that there were going to be smaller class sizes then going to the [name of large university] and I didn't want to jump into big classes, so, so that was one of the main things that made me look at [this school] as a second step in my plan; first school. I started at [a small community college], actually, doing my upgrading and the reason I went there was because it was really, really small because their Aboriginal campus is in the [community] Mall, so it's really small and so I knew this would be another step up to the next level. And I didn't want to go into classes that had like 400 students, that's just like, scared the crap out of me back then ... (Interview Participant D)

In addition to relieving the anxiety associated with some large universities and class sizes, these small classes also helped students build strong peer networks, which positively impacted the students even when they did not believe they would be successful in the class.

For me, it was the small class. Like for science, I don't need science, but my friend was supposed to join school with me and she was like, yeah, I'll help you, and I was like, I hate science but let's do it. And then she didn't end out coming and then I couldn't withdraw from it, so having such a small class and meeting everybody and getting to know then, it helped a lot actually. I'm surprised I passed. I was expecting to fail but [laughter]. (Focus Group Participant \#4) 
Being in a small Aboriginal-centred classroom gave these students the opportunity to meet and develop friendships with other like-minded students, which in turn increased confidence and the belief they could succeed.

Peer support. Finding positive peer support was identified as a key component to remaining in school for most of the participants. For example, comments by several participants suggested that being around other Aboriginal students who shared many of their experiences had a positive impact on their individual motivation to attend a postsecondary institution. It also provided them with a sense of community, which helped them overcome some of the other obstacles, such as being far away from home or worrying that they would not fit in.

I think the support system, having close friends that are in the class. You don't necessarily have to go to your instructor and talk to them about stuff, you can always go to your peers and ask them questions. I think it's a lot easier when, let's say, I was helping someone out with math, it would help me understand it better because I'm explaining what I've just learned to someone else. And plus, not asking your teacher and her explaining it to you or him explaining it to you, which is helpful. (Focus Group Participant \#3)

Thus, students often served as mentors and role models to each other. Some also noted that, although they did not think much about it when starting university, Aboriginal peers and events helped them learn more about their own cultural heritage and Aboriginal cultures other than their own.

\section{Supportive Teaching Strategies}

Positive instructor feedback. Another major theme that emerged in this study was the importance of support from authority figures. Specifically, finding an instructor at the institution who believed in them was a major reason many of these students remained in school.

I've almost dropped out a bunch of times, I've had about a million and ten things happen in the last couple of years and I almost left and I thought I can't do this, this is too hard. And I've had my teachers be like, no, we think you are capable and we want you to stay and we value you here. So that was probably the biggest one ... I guess my authority, I guess my authority figures, my teachers and stuff. Yeah, you sort of make a connection when you are in trouble, you're like, I can't do this, I can't do this, and then someone out of nowhere says, "Actually, I think you can." (Interview Participant A)

Not surprisingly, increased dropout and course failure due to overly negative or critical feedback was identified as a problem by participants in this study. Typically, this problem was identified as a conflict with a professor or Aboriginal student centre staff.

Well, she got, [the instructor] said to her, "Well, your grades aren't looking that good; maybe you should take a semester off." And that hurt her feelings so much to the point where she's not coming back to school next year ... And she was a funded student and I'm not a funded student and she's not coming back because her selfesteem has been hit, you know what I mean? (Interview Participant F) 
As one participant from this study noted, the consequences of not having someone in an authority position believe in you can be devastating.

Clear expectations and feedback. Several participants in this study discussed the importance of having clear expectations in the classroom. Students reported challenges succeeding and remaining in their courses when they were unclear of the overall faculty or course expectations.

The teacher and I just didn't like each other from day one, and at one point I thought that I should have gotten a higher grade than I did in one thing and I went to talk to her in her class, or in her office, and I asked for an explanation on why I got the mark that I did. Because when you hand in a paper and you get it back and there is no corrections, but there's no reasoning why you got such a low mark, you want to know why and at one point during that conversation she said that I'm not as good as I think I am, which I think is totally out of line for a teacher to say to any student. But it was very frustrating because I think she was giving me a lower mark because she wanted to give me a lower mark, not because I deserved a lower mark. (Interview Participant D)

While it is important for all postsecondary education instructors to have clear expectations for all their students, it appears that it might be even more important for marginalized students. Given the findings of this study, it would appear that unclear instructor expectations could further marginalize many of these Aboriginal students by increasing their feelings of self-doubt, inadequacy, and overall alienation.

Finally, another significant theme that emerged from this study was the need for instructors to place realistic expectations on the students. Having low expectations or no expectations translated into the students' perceiving that the instructors did not believe in them, or that they could not complete the course, unless the expectations were lower. As this student states, being given coursework that was too easy was demotivating:

Because I expected organization, structure, there's going to be real tough exams and real tough papers and they're going to mark me for my spelling and my grammar finally. They didn't. I didn't write a paper in the [course] program, not one. And the tests were all just jokes, so it got to the point where you had to show up for the tests, you had to show up for the bake sale, but I just got the grade for absolutely minimal effort so I don't know, I don't know. It wasn't what I wanted, right? (Interview Participant C)

So, although participants in this study discussed the benefits of having instructors who cared about them, if the caring did not include clear expectations, feedback, and an overall belief in their ability, it could easily become a disempowering experience for these students.

\section{Discussion}

Academic success is the responsibility of a number of stakeholders, including the students, institutions, and communities in general (Pidgeon \& Hardy Cox, 2002). Despite the increasing numbers of Aboriginal students in Canada attending postsecondary institutions (Pidgeon, 2001), and the improvements these schools have made, many challenges appear to still exist for Aboriginal students in Canada. 


\section{Creating Supportive Institutional Space}

For the participants of this study, being successful in this postsecondary institution did not come automatically from small class sizes and the opportunity to create connections with peers and faculty. Instead, it was the quality of interactions within these spaces that made the difference. Institutions should be focused on supporting Aboriginal students by helping them "find their gifts" and "maintain their cultural integrity" (Pidgeon, 2008a). As the participants of this study indicated, they needed to find individuals who could help them visualize success by minimizing the negative self-talk and sense of helplessness. Adopting positive self-belief could be a strong motivator for ongoing learning. According to Llorens, Schaufeli, Bakker, and Salanova (2007), having confidence in one's ability could be a strong motivator for a student's ongoing engagement and active learning. Confident students stayed motivated and engaged even in the face of short-term failure.

\section{Creating Supportive Instructional Space}

Similar to Zepke and Leach (2010), this study also found that teaching and teachers are central to engagement and need to create educational experiences for students that are both enriching and challenging. Faculty members who are perceived to be approachable, committed to working hard, unafraid to express their own opinion, and sensitive to student needs are more likely to engage both traditional and nontraditional learners (Bryson \& Hand, 2007; Zepke \& Leach, 2010). For example, in a large U.S. study involving 20 leading colleges, Kuh, Kinzie, Schuh, and Whitt (2005) found that “'tough' assessment tasks enhance rather than hinder engagement as long as such challenges are associated with detailed, swift and focused feedback". The participants of this study found it demotivating to be in a classroom with an instructor who did not challenge them, or believe in them, or provide the students with clear feedback on how to improve. So what appears to be key to ensuring success for Aboriginal students is offering a challenging curriculum, while at the same time providing the necessary individual support to be successful. Specifically, if postsecondary institutions want to retain their Aboriginal students, they will need to place teaching at the centre of their engagement activities. As this study found, students who felt their instructors believed in them, and challenged them, were more likely to believe in themselves and therefore were more likely to work harder and be successful.

\section{Conclusion}

This study developed from general observations and concern about the retention and success rates of Aboriginal students attending a midsized Western Canadian postsecondary educational institution. Regardless of how one measures "success," the fact is the overall retention rate for Aboriginal students in Canada remains lower than for non-Aboriginal postsecondary students (Statistics Canada, 2008). This study is one step to understanding the academic experiences of Aboriginal students and what helps them to remain in school and feel supported. The findings of this study suggest that while concrete motivators, such as small class sizes and the availability of Aboriginal resources, encourage students to pursue postsecondary education, these factors are not specifically what maintain the students' ability to remain in their programs. Instead, the quality of the relationships developed during their academic program may be as important, if not more important, to their eventual academic success. 
Given the great variance among Aboriginal communities in Canada, this study could not possibly capture all the experiences of Aboriginal learners. Further research involving a sampling of Aboriginal students across Canada would provide a better understanding of the specific institutional and instructional strategies needed to engage and retain Aboriginal students in higher education. If postsecondary institutions want to support Aboriginal students in achieving "success" in a meaningful way, what is needed is a better understanding of what "success" means for students in their individual institutions. The development of this new understanding then needs to be formalized and incorporated into both institutional planning and faculty instructional support.

\section{Acknowledgements}

The authors would like to acknowledge the tremendous support and work of the research team involved in this study: Andreas Tomaszewski, Tracy Powell, Chad London, Theresa O'Krane, and Sydney Gyles. We would also like to acknowledge the funding received for this project from the Faculty of Health \& Community Studies and the Office of the Provost and Vice-President Academic at Mount Royal University. Finally, we would like to thank the Aboriginal students who participated in this study, as well as Cory Cardinal from the Students' Union Native Support Centre at Mount Royal University, and Valerie Sipos from the Iniskim Centre at Mount Royal University, whose guidance and generosity made the completion of this project possible.

\section{References}

Aboriginal Education Program. (n.d.). Aboriginal education program [Web page]. Retrieved from Mount Royal University website: http://www. mtroyal.ca/ProgramsCourses/FacultiesSchoolsCentres/IniskimCentre/ AboriginalEducationProgram/index.htm

Alcorn, W., \& Levin, B. (2000). Post-secondary education for Indigenous peoples. Adult Learning, 11(1), 20-25.

Antone, E. (2000). Empowering Aboriginal voice in Aboriginal education. Canadian Journal of Native Education, 24(2), 92-101.

Archibald, J., Pidgeon, M., \& Hawkey, C. (2010). Aboriginal transitions: Undergraduate to graduate (Phase II Final Report). Retrieved from British Columbia Ministry of Advanced Education and Labour Market Development website: http://www. aved.gov.bc.ca/aboriginal/docs/educator-resources/UBC-ATRF-II.pdf

Bandura, A. (1986). Social foundations of thought and action: A social cognitive theory. Englewood Cliffs, NJ: Prentice Hall.

Barnhardt, R. (1992). Higher education in the fourth world: Indigenous people take control. Canadian Journal of Native Education, 18(2), 199-231.

Barnhardt, R. (2002). Domestication of the ivory tower: Institutional adaptation to cultural distance. Anthropology \& Education Quarterly, 33(2), 238-249.

Bastien, B. (2004). Blackfoot ways of knowing: The worldview of the Siksikaitsitapi. Calgary, AB: University of Calgary Press. 
Battiste, M. (2000). Maintaining Aboriginal identity, language and culture in modern society. In M. Battiste (Ed.), Reclaiming Indigenous voice and vision (pp. 192-208). Vancouver: UBC Press.

Battiste, M., \& Barman, J. (Eds.). (1995). First Nations education in Canada: The circle unfolds. Vancouver: UBC Press.

Battiste, M., Bell, L., \& Findlay, L. M. (2002). Decolonizing education in Canadian universities: An interdisciplinary, international, Indigenous research project. Canadian Journal of Native Education, 26(2), 82-95.

Battiste, M., \& Henderson, J. Y. (2000). Protecting Indigenous knowledge and heritage: A global challenge. Saskatoon, SK: Purich Publishing.

Beaudin, L., Gunn, T. M., Heffernan, P., \& Tailfeathers, J. (2006). Making the grade: Monitoring the impact of a mentorship program on Native students' academic achievement. International Journal of Diversity in Organizations, Communities and Nations, 5(5), 83-90.

Bernard, H. R. (2012). Social research methods: Qualitative and quantitative approaches. Thousand Oaks, CA: Sage.

Bryson, C., \& Hand, L. (2007). The role of engagement in inspiring teaching and learning. Innovations in Education and Teaching International, 44(4), 349-362.

Danziger, E. J. J. (1996). Taking hold of the tools: Post-secondary education for Canada's Walpole Island First Nations, 1965-1994. Canadian Journal of Native Studies, 16(2), 229-246.

Deloria, V. (2001). Higher education and self-determination. In V. Deloria \& D. R. Wildcat (Eds.), Power and place: Indian education in America (pp. 123-133). Golden, CO: Fulcrum Resources.

Guillory, R. M., \& Wolverton, M. (2008). It's about family: Native American student persistence in higher education. The Journal of Higher Education, 79(1), 58-87.

Harrington, B. G., \& Pavel., D. M. (2013). Using Indigenous educational research to transform mainstream education: A guide for $\mathrm{P}-12$ school leaders. American Journal of Education, 119, 487-511.

Health Canada. (2013). Indian residential schools health supports. Retrieved from http://www.hc-sc.gc.ca/fniah-spnia/services/indiresident/index-eng.php

Holloway, I., \& Wheeler, S. (2010). Qualitative research in nursing and healthcare (3rd ed.). Oxford, UK: Blackwell.

Huffman, T. (2001). Resistance theory and the transculturation hypothesis as explanations of college attrition and persistence among culturally traditional American Indian students. Journal of American Indian Education, 4O(3), 1-23.

Iniskim Centre (n.d.). Programs [Web page]. Retrieved from Mount Royal University website: http://www.mtroyal.ca/ProgramsCourses/FacultiesSchoolsCentres/Iniskim Centre/index.htm 
Ireland, B. (2009). Moving from the head to the heart: Addressing the "Indian's Canada problem" in reclaiming the learning spirit-Aboriginal learners in education. Saskatoon: University of Saskatchewan, Aboriginal Education Resource Centre and Calgary, AB: First Nations and Adult Higher Education Consortium.

Jackson-Barrett, E. M. (2011). The context for change: Reconceptualising the 3 Rs in education for Indigenous students. Australian Journal of Teacher Education, 36(12). doi:10.14221/ajte.2011v36n12.1

Karabenick, S. A., \& Knapp, J. R. (1991). Relationship of academic help seeking to the use of learning strategies and other instrumental achievement behavior in college students. Journal of Educational Psychology, 83(2), 221-230.

Khan, S. N. (2014). Qualitative research method-Phenomenology. Asian Social Science, $10(21), 298-310$.

Kidd, S. A., \& Kral, M. J. (2005). Practicing participatory action research. Journal of Counseling Psychology, 52(2), 187-195.

Kirkness, V. J., \& Barnhardt, R. (2001). First Nations and higher education: The four r's-respect, relevance, reciprocity, responsibility. In R. Hayoe \& J. Pan (Eds.), Knowledge across cultures: A contribution to dialogue among civilizations (pp. 1-17). Hong Kong: The University of Hong Kong, Comparative Education Research Centre.

Kuh, G., Kinzie, J., Schuh, J., \& Whitt, E. J. (2005). Student success in college: Creating conditions that matter. San Francisco, CA: Jossey-Bass.

Kuokkanen, R. (2007). Reshaping the university: Responsibility, Indigenous epistemes, and the logic of the gift. Vancouver: UBC Press.

Kurpius, S. E. R., Payakkakom, A., Rayle, A. D., Chee, C., \& Arredondo, P. (2008). The appropriateness of using three measures of self-beliefs with European American, Latino/a, and Native American college freshmen. Journal of Multicultural Counseling and Development, 36(1), 2-14.

Leech, N. L., \& Onwuegbuzie, A. J. (2007). An array of qualitative data analysis tools: A call for data analysis triangulation. School Psychology Quarterly, 22(4), 557-584.

Lewin, K. (1946). Action research and minority problems. Journal of Social Issues, 2(4), 34-46.

Lewin, K. (1952). Group decision and social change. In G. E. Swanson, T. M. Newcomb, \& E. L. Hartley (Eds.), Readings in social psychology (pp. 459-473). New York, NY: Henry Holt.

Linnenbrink, E. A., \& Pintrich, P. R. (2003). The role of self-efficacy beliefs in student engagement and learning in the classroom. Reading and Writing Quarterly, 19(2), 119137.

Llorens, S., Schaufeli, W., Bakker, A., \& Salanova, M. (2007). Does a positive gain spiral of resources, efficacy beliefs and engagement exist? Computers in Human Behavior, 23, 825-841.

Manifold, C., \& Rambur, B. (2001). Predictors of attrition in American Indian nursing students. Journal of Nursing Education, 4O(6), 279-281. 
Marshall, H. H. (1992). Seeing, redefining, and supporting student learning. In H. H. Marshall (Ed.), Redefining student learning: Roots of educational change (pp. 1-32). New York, NY: Macmillan.

Martin, D. E., \& Kipling, A. (2006). Factors shaping Aboriginal nursing students' experiences. Nurse Education Today, 26(8), 688-696.

McCaslin, M., \& Good, T. L. (1996). The informal curriculum. In D. C. Berliner \& R. C. Calfee (Eds.), Handbook of educational psychology (pp. 622-670). New York, NY: Macmillan.

McTaggart, R. (1991). Principles for participatory action research. Adult Education Quarterly, 41(3), 168-187.

Morse, J. M., Barrett, M., Mayan, M., Olson, K., \& Spiers, J. (2002). Verification strategies for establishing reliability and validity in qualitative research. International Journal of Qualitative Methods, 1(2), 13-22.

Murray, J. L., Naimoli, P. H., Kagan, R. S., Kirnan, S. M., \& Snider, B. R. (2004). Reflections on the use of undergraduate research to support student affairs assessment. Journal of College Student Development, 45(2), 243-252.

Newman, R. S. (1990). Children's help-seeking in the classroom: The role of motivational factors and attitudes. Journal of Educational Psychology, 82(1), 71-80.

Pajares, F. (1996). Self-Efficacy beliefs in academic settings. Review of Educational Research, 66(4), 543-578.

Pascarella, E. T., \& Terenzini, P. T. (1991). How college affects students: Findings and insights from twenty years of research. San Francisco, CA: Jossey-Bass.

Pidgeon, M. (2001). Looking forward: A national perspective on Aboriginal services in Canadian universities. Unpublished master's thesis, Memorial University of Newfoundland.

Pidgeon, M. (2008a). It takes more than good intentions: Institutional accountability and responsibility to Indigenous higher education (Unpublished doctoral dissertation). University of British Columbia, Vancouver.

Pidgeon, M. (2008b). Pushing against the margins: Indigenous theorizing of "success" and retention in higher education. Journal of College Student Retention: Research, Theory \& Practice, 10(3), 339-360.

Pidgeon, M., Archibald, J. A., \& Hawkey, C. (2014). Relationships matter: Supporting Aboriginal graduate students in British Columbia, Canada. Canadian Journal of Higher Education, 44(1), 1-21.

Pidgeon, M., \& Hardy Cox, D. (2002). Researching with Aboriginal peoples: Practices and principles. Canadian Journal of Native Education, 26(2), 96-106.

Pijl-Zieber, E. M., \& Hagan, B. (2011). Towards culturally relevant nursing education for Aboriginal students. Nurse Education Today, 31(6), 595-600.

Royal Commission on Aboriginal Peoples [RCAP]. (1996). Report of the Royal Commission on Aboriginal Peoples: Vol. 3. Gathering strength. Ottawa, ON: Minister of Supply and Services. 
Ryan, A. M., \& Pintrich, P. R. (1997). "Should I ask for help?” The role of motivation and attitudes in adolescents' help seeking in math class. Journal of Educational Psychology, 89(2), 329-341.

Schuell, T. J. (1996). Teaching and learning in a classroom context. In D. C. Berliner \& R. C. Calfee (Eds.), Handbook of educational psychology (pp. 726-764). New York, NY: Macmillan.

Smith, S. E. (1997). Deepening participatory action research. In S. E. Smith, D. G. Willms, \& N. A. Johnson (Eds.), Nurtured by knowledge: Learning to do participatory action research (pp. 173-364). New York, NY: Apex Press.

Statistics Canada. (2008). Educational portrait of Canada, 2006 census (Catalogue no. 97-560-X). Retrieved from http://www12.statcan.ca/census-recensement/2006/assa/97-560/pdf/97-560-XIE2006001.pdf

Statistics Canada. (2013). Aboriginal peoples in Canada: First Nations people, Métis and Inuit (National Household Survey, 2011; Catalogue no. 99-011-X2011001). Retrieved from http://www12.statcan.gc.ca/nhs-enm/2011/as-sa/99-011-x/99-011-x2011001-eng. pdf Stonechild, B. (2006). The new buffalo: The struggle for Aboriginal post-secondary education in Canada. Winnipeg: University of Manitoba Press.

Tandon, R. (1988). Social transformation and participatory research. Convergence, 21(2/3), 5-14.

Timmons, V.(2009). Retention of Aboriginalstudents in post-secondary institutions in Atlantic Canada: An analysis of the supports available to Aboriginal students. Retrieved from Association of Atlantic Universities website: http://www.atlanticuniversities. $\mathrm{ca} /$ sites/default/files/documents/AAUReportsPublications/Retention\%200f\%20 Aboriginal\%20Students\%20July\%202009.pdf

Tomaszewski, A., Powell, T., Gallop, C., London, C., \& Gyles, S. (2011). The university experience of underrepresented groups: The case of Aboriginal students in Canada. International Journal of Arts and Science, 4(17), 333-344.

Urion, C. (1999). Changing academic discourse about Native education: Using two pairs of eyes. Canadian Journal of Native Education, 23(1), 6-15.

Vygotsky, L. S. (1978). Mind in society: The development of higher psychological processes. Cambridge, MA: Harvard University Press.

Waller, M. A., Okamoto, S. K., Hankerson, A. A., Hibbeler, T., Hibbeler, P., McIntyre, P., \& McAllen-Walker, R. (2002). The hoop of learning: A holistic multisystemic model for facilitating educational resilience among Indigenous students. Journal of Sociology \& Social Welfare, 29(1), 97-116.

Webb, N. M., \& Palincsar, A. S. (1996). Group processes in the classroom. In D. C. Berliner \& R. C. Calfee (Eds.), Handbook of educational psychology (pp. 841-873). New York, NY: Macmillan.

White Shield, R. (2003). Identifying and understanding Indigenous cultural and spiritual strengths in the higher education experience of Indigenous women utilizing a culturally intrinsic research paradigm model (Doctoral dissertation). Retrieved from http://lib.dr.iastate.edu/rtd/761 
Wigfield, A., Eccles, J. S., \& Rodriguez, D. (1998). The development of children's motivation in school contexts. Review of Research in Education, 23, 73-118.

Wildcat, D. R. (2001). Indigenizing education: Playing to our strengths. In V. Deloria \& D. R. Wildcat (Eds.), Power and place: Indian education in America (pp. 7-19). Golden, CO: Fulcrum Resources.

\section{Contact Information}

Cynthia J. Gallop

Department of Child Studies and Social Work

Mount Royal University

cgallop@mtroyal.ca

Cynthia Gallop is an associate professor in the Department of Child Studies and Social Work at Mount Royal University. She holds a BSW from the University of Victoria, and a MSW and PhD from the University of Calgary. Her postgraduate career was spent working as a consultant to nonprofit organizations in the area of policy and program development and evaluation. She has combined her passion for making programs more equitable and accessible to diverse individuals, with her research interests, which include student engagement, organizational change, community service-learning, participatory action research, and interpretive research approaches.

Nicole Bastien is a member of the Piikani First Nation in southern Alberta. She obtained her diploma from Mount Royal University before completing a BSW and ultimately a MSW through the Faculty of Social Work at the University of Calgary. Nicole completed a clinical MSW, specializing in an anti-oppressive practice and an Aboriginal framework to complement her approach in working with various populations. Nicole's past experience is concentrated on disenfranchised populations, encompassing homelessness, addictions, mental health, women's issues, and Aboriginal experiences. Nicole is currently employed at a trauma-informed residential treatment centre for women in Calgary, Alberta. 